American Journal of Applied Sciences 7 (6): 795-799, 2010

ISSN 1546-9239

(C) 2010Science Publications

\title{
Simulation of Heat Flow in Computational Method and Its Verification on the Structure and Property of Gray Cast Iron
}

\author{
S.K. Shaha and M.M. Haque \\ Department of Manufacturing and Materials Engineering, \\ International Islamic University Malaysia, P.O. Box 10, 50728, \\ Kuala Lumpur, Malaysia
}

\begin{abstract}
Problem statement: The solidification of materials depends on the cooling rate of the materials which is governed by heat flow in the mould and alloy composition. Solidification rate also affects the structure and properties of the materials. Approach: In the present study, the heat flow of cold set resin bonded sand mould was simulated using JL Analyzer FEM analysis software. To verify the model, the gray cast iron was melted at $1350^{\circ} \mathrm{C}$ temperature and poured into a resin bonded sand mould at $1300^{\circ} \mathrm{C}$. Results: It showed that most of the heat-reserve at the junction of the mould which was nearer to the source of liquid metal and the lowest heat-reserve at the end of the mould. So, the solidification rate was very high at the end of the mould wall whereas it was comparatively low near the sprue of the mould. Conclusion: Finally, depending on the heat-flow through the mould, the solidification rate changed the microstructure from chill, mottled and gray cast iron and hardness changed from 95.1 HRB-78.78 HRB.
\end{abstract}

Key words: Heat transfer, FEM, solidification, hardness

\section{INTRODUCTION}

Casting is the most important process in manufacturing and sand casting is the most convenient process in foundry. Most of the liquid metal can be poured into the sand mould and any size can be cast. So, this sand casting becomes popular day by day. Nowadays, people are using powerful software and programme to control the quality of the materials which reduce the wastage of materials and reduce the cost of the final product.

Solidification rate of molten metal in the sand mould depends on the thermal conductivity of the mould material, casting design and the direction of heat-flow into the mould wall. If the heat-flow through the mould is very quick, the solidification rate will be high at that point and will affect the microstructure and properties of the materials. Heat-flow through the sand mould was studied by many researchers (Seetharamu et al., 2001; Pequet et al., 2002; Sulaiman and Hamouda, 2004; Mirbagheri et al., 2004; Lee and Lee, 2005; Kulkarni and Radhakrishna, 2007; Kermanpur et al., 2008; Hsu et al., 2009; Fras et al., 2005a; 2005b; Collini et al., 2008). Seetharamu et al. (2001) studied the solidification phenomena in sand mould for thermal stress using FEA and they discussed about the effect of solidification on stress formation in casting. Pequet et al. (2002) studied the defects formation during solidification of $\mathrm{Al}$ alloy using ABAQUS and showed that most of the defects formed where the metal solidified last. Sulaiman and Hamouda (2004) investigated the thermal history of the sand casting process for mould filling time using FORTRAN. They have shown that the lastly solidifying area is near the junction. Mirbagheri et al. (2004) studied on the melt flow and effect of mould roughness of sand mould. Lee and Lee (2005) studied on the thermo mechanical behavior of sand casting using FEA. Kulkarni and Radhakrishna (2007) studied on the solidification time of a cylinder in sand mould in FEM technique using ANSYS FEM package. Kermanpur et al. (2008) studied on the melt flow and solidification in the multi-cavity mould for gray cast iron. Hsu et al. (2009) investigated on the multiple-gate runner system for gravity casting in sand mould in computational method. Fras et al. (2005a; 2005b) studied on the transition from gray to white during solidification for both mathematically and experimentally. They conclude that solidification rate depends on the modulus of the casting and the heat flow through the mould that is molding materials.

Most of the researchers used aluminum alloy and green sand mould for their studies. However, the work

Corresponding Author: S.K. Shaha, Department of Manufacturing and Materials Engineering,

International Islamic University Malaysia, P.O. Box 10, 50728, Kuala Lumpur, Malaysia 
on heat flow from gray cast iron through resin bonded sand mould is very limited. So, in the present study, an attempt has been made to simulate the heat flow condition that is how the heat flows through the resin bonded sand mould and in the most heated area, during casting as well as to see its effect on the microstructure and hardness of the cast product. Finally, these all have also been correlated with the simulated model.

\section{MATERIALS AND METHODS}

The whole study divides into two parts; firstly, the prediction of heat flow through the mould wall and secondly, through the casting of gray cast iron.

Simulation of heat flow: The heat flow was simulated using JL Analyzer, Auto FEM software. The following variables are considered for this model.

No heat losses occurred before filling the mould; the chemical composition of the gray cast iron is shown in Table 1 while the thermal properties of metal and resin bonded sand mould are shown in Table 2 .

Figure 1 shows the 2D drawing of the pattern where mesh was generated using JL Analyzer FEM software. The mesh length was $5 \mathrm{~mm}$ and the materials properties were defined in the software.

The mesh was loaded in the experimental condition that is the boundary conditions and then the initial conditions are applied. By running the analysis software, the heat flow through the mould was simulated.

Molding and casting: For this study 60 mesh synthetic silica sand, cold set Asphalt resin and Alpha cure hardener were used as molding materials. To make the mould silica sand was mixed with $2 \%$ resin for 5 min.

\begin{tabular}{ll}
\multicolumn{2}{l}{ Table 1: Chemical composition of the cast alloy } \\
\hline Chemical elements & Gray iron chemical composition (wt $\%)$ \\
\hline $\mathrm{C}$ & 2.870 \\
$\mathrm{Si}$ & 2.930 \\
$\mathrm{Al}$ & 0.150 \\
$\mathrm{Mn}$ & 0.350 \\
$\mathrm{P}$ & 0.040 \\
$\mathrm{~S}$ & 0.020 \\
$\mathrm{Cr}$ & 0.064 \\
$\mathrm{Cu}$ & 0.244 \\
$\mathrm{Mg}$ & 0.002 \\
\hline
\end{tabular}

Table 2: Thermal properties of the materials

\begin{tabular}{lcr}
\hline Properties & $\begin{array}{l}\text { Resin bonded } \\
\text { sand mould }\end{array}$ & \multicolumn{1}{l}{$\begin{array}{l}\text { Gray cast } \\
\text { iron }\end{array}$} \\
\hline Thermal conductivity $\left(\mathrm{W} \mathrm{m}^{-1} \cdot \mathrm{K}\right)$ & 0.981 & 32.30 \\
Density $\left(\mathrm{g} \mathrm{cm}^{-3}\right)$ & 1.770 & 7.10 \\
Specific heat $\left(\mathrm{J} \mathrm{Kg}^{-1} \cdot \mathrm{K}\right)$ & 735.000 & 0.42 \\
Latent heat of graphite $\left(\mathrm{J} \mathrm{cm}^{-3}\right)$ & - & 2028.80 \\
Latent heat of austenite $\left(\mathrm{J} \mathrm{cm}^{-3}\right)$ & - & 1904.40 \\
Liquidus temperature $\left({ }^{\circ} \mathrm{C}\right)$ & - & 1195.00 \\
Solidus temperature $\left({ }^{\circ} \mathrm{C}\right)$ & - & 1123.00 \\
\hline
\end{tabular}

Then, $1 \%$ cold set hardener was used and continued the mixing for $1 \mathrm{~min}$. Using this freshly prepared sand mixture, the mould was prepared.

To melt the raw material, medium frequency induction furnace was used. Firstly, pig iron and mild steel were melted together and heated up to about $1350^{\circ} \mathrm{C}$. Then, fluxing material was added into the melt and stirred the melt thoroughly. Then, the slag was removed and ferrosilicon was added into the melt. Again, the fluxing material was added and slag was removed by keeping the melt in the furnace. When the melt was ready, the liquid metal was poured into the mould at about $1300^{\circ} \mathrm{C}$.

For metallographic study, the sample was prepared by standard technique used in. Hardness values (HRB) of the casting were taken from $10 \mathrm{~mm}$ thickness to $2 \mathrm{~mm}$ thickness area using Rockwell hardness tester, Model: 660RLD/T.

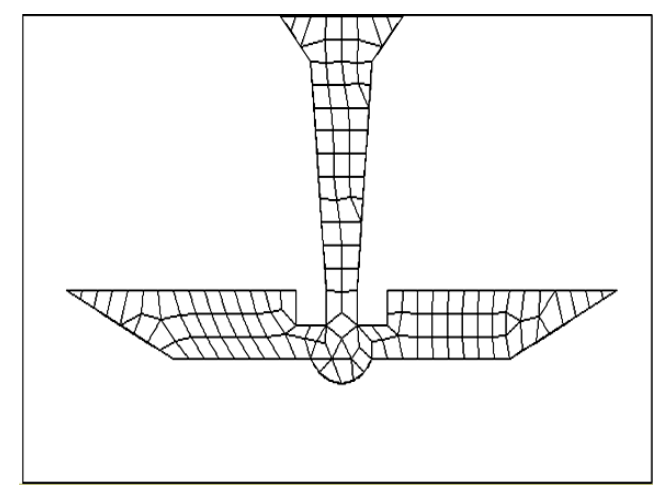

Fig. 1: Pattern loaded in FEM software

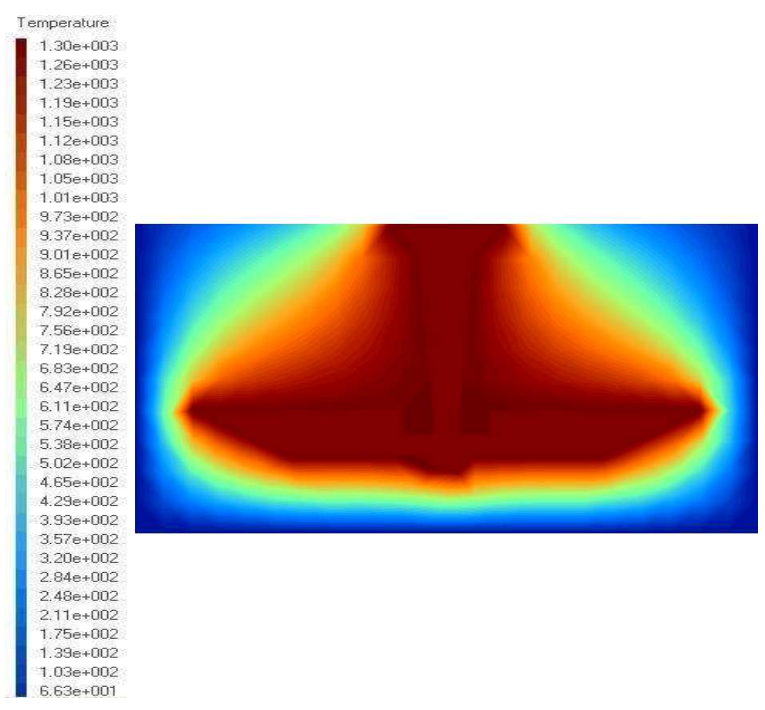

Fig. 2: Predicted heat flow of the sand mould using FEM software 
Heat flow through the sand mould: The predicted heat flow condition through the sand mould is shown in Fig. 2. It shows that most of the heat energy is concentrated near the sprue where the thickness of the casting is $10 \mathrm{~mm}$. When the casting thickness changes from $10-2 \mathrm{~mm}$, the intensity of the heat energy also decreases.

Microstructure: The microstructure was observed under optical microscope and is shown in Fig. 3. It indicates that the 10-2 $\mathrm{mm}$ thickness areas show different microstructures due to different heat dissipation rates as already described in Fig. 2. However, Fig. 3 shows that there are three distinguished structural differences available in the casting. Gary area for $10 \mathrm{~mm}$ thickness which consists of graphite flakes in pearlite; mottle area for 7-4 $\mathrm{mm}$ thickness which consists of mixture of gray and chill/white cast iron and last 3-2 mm thickness which is completely chill/white cast iron.

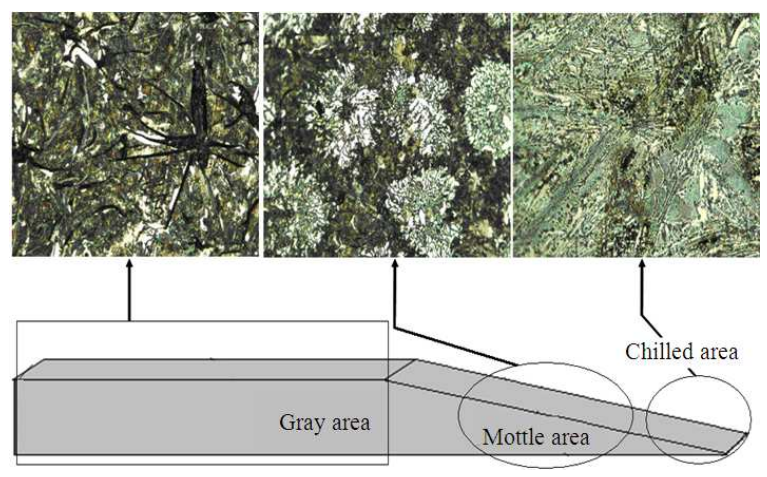

Fig. 3: Microstructure of cast iron in various thicknesses

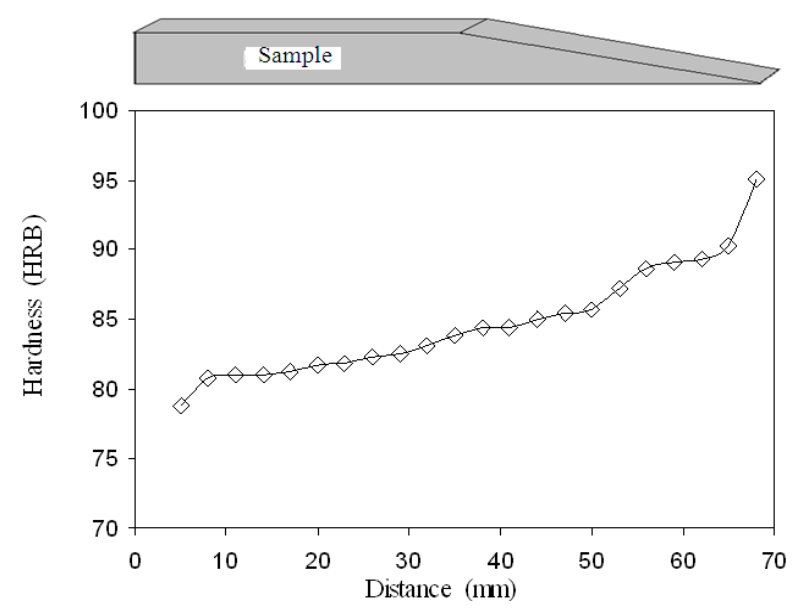

Hardness values: Figure 4 shows the various hardness values of the cast product due to different thickness which is governed by the heat flow through the sand mould. It is clear that with decreasing the thickness, the hardness increases from 78.71 HRB95.10 HRB.

\section{RESULTS AND DISCUSSION}

The heat flow through the sand mould can be explained below using well established heat flow equations.

Fourier's Law of Conduction states that the rate of heat flow through solid material is directly proportional to the cross sectional area and the temperature difference along the path of heat flow. So, the following equation can be written from this definition as:

$q=-k A \frac{d T}{d x}$

Where:

$\mathrm{A}=$ The cross-sectional area

$\mathrm{k}=$ Materials thermal conductivity

$\mathrm{dT} / \mathrm{dx}=$ The temperature difference along the path

From the Eq. 1, the rate of heat flow decreases when the thickness increases.

On the other hand, Newton's Law of Cooling states that the rate of change of the temperature of an object is proportional to the difference between its own temperature and the ambient temperature. So, the following equation can be written from this definition as:

$\frac{\mathrm{dT}}{\mathrm{dt}}=-\mathrm{k}\left(\mathrm{T}-\mathrm{T}_{\mathrm{a}}\right)$

where, $T$ and $T_{a}$ representing the temperatures of melt and mould, respectively.

The sand mould is not a completely compacted solid and there are a lot of pores which are filled with air and this air is considered as fluid (Sulaiman and Hamouda, 2004). The heat transfer from a solid surface to a fluid can be written as follows:

$\mathrm{Q}=\alpha \mathrm{A}\left(\mathrm{T}-\mathrm{T}_{\mathrm{a}}\right)$

The total heat energy, $\mathrm{Q}$ in the liquid metal can be shown using the following equation:

$\mathrm{Q}=\mathrm{V} \rho \mathrm{L}$

Fig. 4: Hardness of the casting from 10-2 mm thickness 
Where:

$\mathrm{V}=$ The volume of the materials

$\rho=$ The density of the liquid

$\mathrm{L}=$ The latent heat of the materials

So, if the casting thickness is low, the total heat energy at that point will be low and will dissipate quickly. However for higher thickness, it will be just reverse.

The volume of the $10 \mathrm{~mm}$ thickness area is higher than that of $2 \mathrm{~mm}$ thickness area. According to the Eq. 4, density and latent heat of the materials are constant, so the total heat energy in the mould is proportional to the volume of the liquid metal which is higher in the $10 \mathrm{~mm}$ thickness area and sand in this area becomes more heated than $2 \mathrm{~mm}$ thickness area. At the same time, the heat extraction rate is higher in the $2 \mathrm{~mm}$ thickness area than the $10 \mathrm{~mm}$ thickness area. As a result, the hardness values and microstructures of cast iron are different from one end to the other end of the casting, which has been demonstrated in Fig. 4.

The different micro structural development was due to the cooling rate of the melt. The graphite flake is eutectic cell which is formed during slow cooling before the eutectoid isothermal temperature starts (Elliott, 1988). When the heat energy is high, the heat flows through the sand mould is low which reduces the solidification rate of the cast iron. As a result, eutectic graphite cell is formed. Again, in the low thickness area, the absorption of heat energy in the sand mould is high which increases the solidification rate of the cast iron. However, it does not get enough time to form eutectic graphite cell but the austenite which changes to cementite and pearlite. As $10 \mathrm{~mm}$ thickness area shows gray cast iron and $2 \mathrm{~mm}$ thickness area shows white/chill cast iron, thus the hardness increases with decreasing the thickness.

Significance and limitation: The main assumption of the model is no heat loss before completely filling the mould but in practice as soon as liquid metal enters into the mould cavity, it starts to fall its temperature and changes the microstructure. The simulation shows that the most heated area is near the sprue where the thickness is $10 \mathrm{~mm}$. However, it is not only the thickness but also the junction of the design. Similar observation was reported by Sulaiman and Hamouda (2004).

\section{CONCLUSION}

From the present study, the following conclusions can be drawn:
- The simulated and experimentally verified results show similar behavior

- The simulation shows that total heat energy increases with increasing the thickness of cast iron

- The microstructure becomes different due to differential heat flow through the sand mould, although the chemical composition of the melt is the same

- The hardness values change from 78.78-95.1 HRB due to differential heat flow through the sand mould from gray to chill area

\section{ACKNOWLEDGMENT}

Researchers are thankful to the Faculty of Engineering and Research Management Centre of International Islamic University Malaysia for providing lab facilities and financial support.

\section{REFERENCES}

Collini, L., G. Nicoletto and R. Konecna, 2008. Microstructure and mechanical properties of pearlitic gray cast iron. Mater. Sci. Eng. A., 488: 529-539. DOI: 10.1016/j.msea.2007.11.070

Elliott, R., 1988. Cast Iron Technology. 1st Edn., Butterworth and Co., UK., ISBN: 0408015128, pp: 31.

Fras, E., M. Gorny and H.F. Lopez, 2005a. The transition from Gray to white cast iron during solidification: Part I. theoretical background. Metallurgical Mater. Trans. A., 36: 3075-82. DOI: 10.1007/s11661-005-0079-2

Fras, E., M. Gorny and H.F. Lopez, 2005b. The transition from gray to white cast iron during solidification: Part II. Experimental verification. Metallurgical Mater. Trans. A., 36: 3083-92. DOI: 10.1007/s11661-005-0080-9

Hsu, F.Y., M.R. Jolly and J. Campbell, 2009. A multiple-gate runner system for gravity casting. J. Mater. Process. Technol., 209: 5736-5750. DOI: 10.1016/j.jmatprotec.2009.06.003

Kermanpur, A., S. Mahmoudi and A. Hajipour, 2008. Numerical simulation of metal flow and solidification in the multi-cavity casting moulds of automotive components. J. Mater. Process. Technol., 206: 62-68. DOI: 10.1016/j.jmatprotec.2007.12.004

Kulkarni, S.N. and K. Radhakrishna, 2007. Prediction of solidification time of cylindrical hollow casting cast in $\mathrm{CO}_{2}$-Sand moulds by using FEM technique. Int. J. Mater. Sci., 2: 137-152. 
Lee, S.M. and W.J. Lee, 2005. Finite-element analysis on thermo mechanical behavior of a marine propeller casting in the sand casting process. J. Mater. Eng. Perform., 14: 388-394. DOI: 10.1361/10599490523931

Mirbagheri, S.M.H., M. Dadashzadeh, S. Serajzadeh, A. K. Taheri and P. Davami, 2004. Modeling the effect of mould wall roughness on the melt flow simulation in casting process. Applied Math. Model., 28: 933-956. $\quad$ DOI: 10.1016/j.apm.2004.03.007

Pequet, C., M. Gremaud and M. Rappaz, 2002. Modeling of microprosity, macroporosity and pipeshrinkage formation during the solidification of alloys using a mushy-zone refinement method: Applications to aluminum alloys. Metallurg. Mater. Trans. A., 33: 2095-2106. DOI: 10.1007/s11661002-0041-5
Seetharamu, K.N., R. Paragasam, G.A. Quadir, Z.A. Zainal, B.S.A. Prasad and T. Sundararajan, 2001. Finite element modeling of solidification phenomena. Sadhana, 26: 102-120.

Sulaiman, S. and A.M.S. Hamouda, 2004. Modeling and experimental investigation of solidification process in sand casting. J. Mater. Process. Technol., 155-156: 1723-1726. DOI: 10.1016/j.jmatprotec.2004.04.153 